Bangladesh J. Bot. 43(2): 175-181, 2014 (September)

\title{
EFFECTS OF GRANULAR AND LIQUID FERTILIZERS ON PHYTOPLANKTON UNDER EXPERIMENTAL POND CONDITION
}

\author{
B Tizkar, AR Seidavi ${ }^{1}$, M Sudagar ${ }^{2}$ and JT Ponce-Palafox ${ }^{3 *}$ \\ Mirza Koochak Khan, Higher Education Fisheries Research, Rasht, Iran \\ Key words: Phytoplankton, Photosynthesis, Water quality, Fertilizers
}

\begin{abstract}
Under the experimental pond condition, three treatments of fertilizers on phytoplankton were carried out. The first treatment was with granular fertilizers (GF), and the second and third treatments were with liquid fertilizer A (LFA), low concentration and liquid fertilizer B (LFB), high concentration, respectively. The mean $\mathrm{pH}$ and the average transparency of the water varied significantly among different treatments $(\mathrm{p}<0.05)$. Gross and net productivity in the LFB-treated ponds were higher than those observed in the two other treatments $(p<0.05)$. In addition, the bacillariophytes did not change significantly among treatments $(p<0.05)$. However, the chlorophytes increased in the LFB treatment, and the cyanophytes were increased in the GF treatment $(\mathrm{p}<0.05)$.
\end{abstract}

\section{Introduction}

Fertilization of fish ponds by granular and liquid fertilizers is a common practice. Geiger (1983) suggested that liquid fertilizers have several advantages over the traditionally used granular inorganics. These advantages include faster solubilization and dispersion of nitrogen and phosphorus throughout the water column (Davidson and Boyd 1981), which can bring about greater phytoplankton diversity and concentrations, and ease of application for large-scale operations (Nicholson 1983). Some disadvantages of liquid fertilizers include their limited availability in many areas and higher costs as well as the need for specialized equipment to safely store and apply these highly caustic liquids. There is a lack of data comparing the relative effectiveness of liquid and granular fertilizers in ponds. Davidson and Boyd (1981) found that liquid was superior to granular fertilizer in promoting phytoplankton abundance; however, they spread the granular fertilizer in shallow water and allowed it to settle rapidly to the bottom. Granular fertilizers can be more effectively applied by being placed on underwater platforms, which prevent the fertilizer from settling to the bottom and being absorbed by the sediments (Boyd 1979). Boyd (1981) found that various granular fertilizers almost totally dissolved within 24 hrs when applied correctly, and diammonium phosphate was one of the most soluble granular fertilizers tested. Liquid inorganic fertilizers much more efficiently strengthen fish pond food chains than granular fertilizers do. Granules of solid fertilizer sink, so that most of the dissolution occurs at the mud surface, which favors uptake of P by the mud rather than the plankton (Boyd et al. 1981). Thus, more of the $\mathrm{P}$ in liquid fertilizers is available to plants. The response of phytoplankton to implementing nutrients has been studied, usually in ponds with soil (Mischke and Zimba 2004, Ansa and Akinwale 2007, Ponce-Palafox et al. 2010). However, studying the response of phytoplankton to the application of nutrients to the water in conditions without soil

\footnotetext{
*Author for correspondence: <jesus.ponce@usa.net>. ${ }^{1}$ Animal Science Department, Rasht Branch, Islamic Azad University, Rasht, Iran. ${ }^{2}$ Fishery Sciences Department, Gorgan University of Agricultural Sciences and Natural Resources, Gorgan, Iran. ${ }^{3}$ Universidad Autónoma de Nayarit. Escuela Nacional de Ingeniería Pesquera. Lab. de Bioingeniería Costera. Centro Multidisciplinario de Bahía de Banderas, Nayarit. México.
} 
would lead to a better understanding of phytoplankton's response to the application of commercial fertilizer. In the present experiment, the effects of granular and liquid fertilizers on the species composition and density of phytoplankton under experimental pond conditions have been carried out.

\section{Materials and Methods}

The experiment was conducted at the farm of the Agriculture Faculty of Islamic Azad University, in Rasht, Iran. Over 23 days, from 4 to 27 May, 2011. Nine 300 liter fiberglass ponds $(0.6 \times 0.5 \times 1.0 \mathrm{~m})$ were distributed in a randomized design, and we applied three types of fertilizers namely, granular fertilizers (GF), liquid fertilizer LFA (low concentration) and liquid fertilizer LFB (high concentration) were applied. The ponds were placed outdoors, and each contained water that came from an irrigation canal. For the initial elimination of zooplanktons that prevent the development of phytoplankton, $1 \mathrm{mg} / \mathrm{l}$ of trichlorphon (phosphonic acid) was added shortly after water was introduced to the ponds. After one hour of de-toxification, phosphate and nitrogen fertilizers at a ratio of $1: 1$ were added to the ponds.

The compositions of fertilizers were as follows: liquid fertilizer LFA: $\mathrm{NO}_{3}=8 \%, \mathrm{P}_{2} \mathrm{O}_{5}=4 \%$, $\mathrm{K}_{2} \mathrm{O}=5 \%, \mathrm{Fe}=3000 \mathrm{ppm}, \mathrm{Zn}=1500 \mathrm{ppm}, \mathrm{Mn}=1500 \mathrm{ppm}, \mathrm{Cu}=1200 \mathrm{ppm}, \mathrm{B}=1000 \mathrm{ppm}$; liquid fertilizer LFB: $\mathrm{NO}_{3}=10 \%, \mathrm{P}_{2} \mathrm{O}_{5}=6 \%, \mathrm{~K}_{2} \mathrm{O}=8 \%, \mathrm{Fe}=3000$ ppm, $\mathrm{Zn}=1500 \mathrm{ppm}, \mathrm{Mn}=$ $1500 \mathrm{ppm}, \mathrm{Cu}=1200 \mathrm{ppm}, \mathrm{B}=1000 \mathrm{ppm}$; and granular fertilizer (GF): Urea + diammonium phosphate $\left(\mathrm{NH}_{2}\right) 2 \mathrm{Co}+\left(\mathrm{NH}_{4}\right) 2 \mathrm{HPO}_{4}$. The total mineral levels were determined through acid extraction (using nitric acid with perchloric acid) (Martin et al. 1994). The level of nitrogen was determined by the Kjeldahl method, and carbon monoxide was measured using the Walkley-Black method (Sherrod et al. 2002). The phosphorus content was determined by colorimetric using vitamin C as the reductant (Whatanabe and Olsen 1965). The calcium, magnesium, copper, iron, manganese and zinc levels were determined using an atomic absorption spectrophotometer, and the sulphur and boron levels were determined by colourimetry (AOAC 1995).

The physical and chemical water parameters were measured. The temperature and dissolved oxygen were measured with a digital oximeter, the $\mathrm{pH}$ was measured with a digital $\mathrm{pH}$ meter (YSI 55 digital oxygen meter with an integrated thermometer, Yellow Springs Instruments, Yellow Springs, OH, USA), and the transparency was measure using a Secchi disc. The ammonia, nitrogen, and orthophosphate levels were measured in the laboratory (YSI 9000 colorimeter). The net and gross photosynthetic rates were measured after Arredondo-Figueroa and Ponce-Palafox (1998) and Dodds and Wiles (2010).

To determine the composition and abundance of phytoplankton, samples were collected weekly during the interval between the two fertilizing instances of the experimental ponds. After collection the samples were fixed in formaldehyde and enumerated microscopically in the laboratory (Utermöhl 1958, Aktan et al. 2005, Stirling 1985).

Analysis of variance was used to detect significant differences in physiochemical and biological factors between treatments. Treatments were compared using Tukey's test $(\mathrm{p}<0.05)$. The analyses were performed using the Statistica Software, version 10 (Statsoft Inc. Tulsa, Oakland, USA).

\section{Results and Discussion}

The water temperature in the ponds ranged from $19.8-29.1^{\circ} \mathrm{C}$, with a mean of $24.6^{\circ} \mathrm{C}$ during the experimental period. The water temperatures for all the treatments did not differ significantly $(\mathrm{p}<0.05)$ throughout the study (Table 1$)$. The temperature in all of the experimental ponds followed a similar trend. The $\mathrm{pH}$ in all the experimental ponds were alkaline during the study and 
was significantly higher $(\mathrm{p}<0.05)$ in the LFB treatment. Significant $\mathrm{pH}$ differences $(\mathrm{p}<0.05)$ between the liquid and granular fertilizers were found. The highest $\mathrm{pH}$ value recorded was from the liquid fertilizer LFB $(10.1 \pm 0.6)$ treatment, and the lowest was found in the GF $(9.5 \pm 0.4)$ treatment. The liquid fertilizers LFA and LFB increased the $\mathrm{pH}$ level of water more than the granulated fertilizer. This result is due to the higher photosynthetic capacities of the ponds in which the liquid fertilizers were used, which may be a result of the lowered oxygen solubility and the abundance of organic materials, including the phytoplankton cells. Ghosh and Chattopadhyay (2005) showed that increased algal blooms are associated with an increase in water $\mathrm{pH}$. The lowest water transparency was recorded in the LFB treatment $(25.1 \pm 7.7 \mathrm{~cm})$, and the highest was found in the treatment with GF $(33.6 \pm 1.6 \mathrm{~cm})$. The LFB treatment induced greater algal population density. The highest concentration of dissolved oxygen was measured in the LFB-treated ponds $(13.23 \pm 2.61 \mathrm{mg} / \mathrm{l})$. Difference in algal density created a significant difference $(\mathrm{p}<0.05)$ in the average dissolved oxygen level in water that received LFB compared with the two other treatments.

Table 1.Water quality variables of the experimental system under investigation.

\begin{tabular}{lccc}
\hline Parameter & \multicolumn{3}{c}{ Treatment (Mean \pm SD) } \\
\cline { 2 - 4 } & $24.28 \pm 1.88^{\mathrm{a}}$ & $24.44 \pm 1.89^{\mathrm{a}}$ & $24.60 \pm 1.99^{\mathrm{a}}$ \\
\hline Temperature $\left({ }^{\circ} \mathrm{C}\right)$ & $9.49 \pm 0.42^{\mathrm{c}}$ & $9.81 \pm 0.39^{\mathrm{b}}$ & $10.11 \pm 0.59^{\mathrm{a}}$ \\
$\mathrm{pH}$ & $33.63 \pm 1.64^{\mathrm{a}}$ & $31.70 \pm 4.94^{\mathrm{a}}$ & $25.11 \pm 7.58^{\mathrm{b}}$ \\
Transparency $(\mathrm{cm})$ & $11.49 \pm 1.65^{\mathrm{b}}$ & $10.97 \pm 2.35^{\mathrm{ab}}$ & $13.23 \pm 2.61^{\mathrm{a}}$ \\
Dissolved oxygen $(\mathrm{mg} / \mathrm{l})$ & $0.34 \pm 0.09^{\mathrm{a}}$ & $0.37 \pm 0.16^{\mathrm{a}}$ & $0.41 \pm 0.16^{\mathrm{a}}$ \\
Ammonium nitrogen $(\mathrm{mg} / \mathrm{l})$ & $2.38 \pm 2.41^{\mathrm{a}}$ & $1.57 \pm 1.32^{\mathrm{a}}$ & $2.58 \pm 2.52^{\mathrm{a}}$ \\
Orthophosphate $(\mathrm{mg} / \mathrm{l})$ & $89.00 \pm 42.46^{\mathrm{b}}$ & $66.23 \pm 30.80^{\mathrm{ab}}$ & $114.76 \pm 56.26^{\mathrm{a}}$ \\
Gross productivity $\left(\mathrm{mg} / \mathrm{c} / \mathrm{m}^{3} / \mathrm{h}\right)$ & $28.25 \pm 26.44^{\mathrm{b}}$ & $44.52 \pm 35.53^{\mathrm{ab}}$ & $32.73 \pm 26.80^{\mathrm{a}}$ \\
\hline Net productivity $\left(\mathrm{mg} / \mathrm{c} / \mathrm{m}^{3} / \mathrm{h}\right)$ & &
\end{tabular}

There is significant difference between the numbers that are shown with the different letter(s) in each row $(\mathrm{p}<0.05)$.

There were no significant differences $(\mathrm{p}<0.05)$ in ammonium nitrogen and dissolved orthophosphate contents in all treatments, but the concentrations of ammonium and orthophosphate tended to be higher in LFB treatment. This result shows that the solubility of nitrogen- and phosphorous-based biogenic materials in LFB is greater than those in the two other fertilizers. A downward trend in the amount of ammonium nitrogen and orthophosphate occurred in all the treatment ponds after fertilization. However, this decline in biogenic substances was higher in granular fertilizer treatment than the two other treatments. The intensity of the decline in ammonium nitrogen in the water column is closely related to the algal density and the sedimentation rate of these substances on the bottom of fish ponds (Jana and Roy 1986).

One of the major factors studied in this experiment was the quantity of gross photosynthesis in different treatments. The results showed that there are significant differences in different treatments $(\mathrm{p}<0.05)$. The highest recorded gross production level of carbon was in the LFBtreated ponds, at $114.76 \pm 56.26 \mathrm{mg} / \mathrm{c} / \mathrm{m}^{3} / \mathrm{h}$, and the lowest level was observed in LFA treatment $\left(66.235 \pm 30.808 \mathrm{mg} / \mathrm{c} / \mathrm{m}^{3} / \mathrm{h}\right)$. A comparison of the photosynthetic products among treatments shows that the average net and gross photosynthetic production was significantly $(\mathrm{p}<0.05)$ higher in each pond receiving LFB than in those receiving the two other treatments. Our results show that the use of LFB led to a greater amount of both net and gross photosynthetic carbon formation 
within a 24-hrs period $(\mathrm{p}<0.05)$, which indicates the greater photosynthetic production capacity of LFB over the GF.

The phytoplankton from different treatments showed that similar algal population (in terms of family) were formed and developed in all three treatments, but the density of each algal family tended to fluctuate among different treatments. In this study, three classes of planktonic algae, namely Bacillariophyceae, Chlorophyceae and Cyanophyceae, were found. Among these, certain species appeared with varying density, including Actinastrum, Nitzschia, Schroederia, Scendesmus, Micractinium, Ankistrodesmus, Oscillatoria, and Spirulina (Table 2). However, algae such as Melosira, Coelastrum, Crucigeniua, Dictyosphaerium, Kirchneriella, Oocystis, Golenkina, Staurastrum, Tetrastrum, Anabaena, Merismopedia, Synedra and Pediasrtum were sporadically found. The results did not show any significant differences $(\mathrm{p}<0.05)$ between the numbers of Nitzschia, Actinastrum and Schroederia algae that occurred in different treatments. The concentration of Osillatoria and Spirulina in the GF-treated pond was significantly higher $(\mathrm{p}<0.05)$ and the concentrations of Ankistrodesmus, Micrasterias and Scenedesmus were significantly higher $(\mathrm{p}<0.05)$ in ponds treated with LFB. The results obtained from the algal density assays for Chlorophyceae, Cyanophyceae and Bacillariophyceae showed that the Bacillariophyceae numbers did not vary significantly during the three treatments. The highest significant concentration $(\mathrm{p}<0.05)$ of chlorophyte algae was found in LFB treatment, and the cyanophytes were most abundant in GF treatment.

Table 2. Phytoplankton abundance of main species recorded in treatments (log (cells/l).

\begin{tabular}{lccc}
\hline Specie & \multicolumn{3}{c}{ Treatments (Mean \pm SD) } \\
& GF & LFA & LFB \\
\hline Nitzschia & $5.82 \pm 0.72^{\mathrm{a}}$ & $5.69 \pm 0.41^{\mathrm{a}}$ & $6.34 \pm 0.58^{\mathrm{a}}$ \\
Actinastrum & $5.63 \pm 0.47^{\mathrm{a}}$ & $5.04 \pm 0.69^{\mathrm{a}}$ & $5.67 \pm 0.54^{\mathrm{a}}$ \\
Ankistrodesmus & $5.48 \pm 0.42^{\mathrm{b}}$ & $5.70 \pm 0.36^{\mathrm{ab}}$ & $6.43 \pm 0.84^{\mathrm{a}}$ \\
Micrasterias & $5.33 \pm 0.54^{\mathrm{b}}$ & $5.82 \pm 0.95^{\mathrm{b}}$ & $6.38 \pm 0.71^{\mathrm{a}}$ \\
Scenedesmus & $5.68 \pm 0.28^{\mathrm{b}}$ & $6.13 \pm 0.54^{\mathrm{ab}}$ & $6.83 \pm 0.83^{\mathrm{a}}$ \\
Schroderia & $6.16 \pm 0.88^{\mathrm{a}}$ & $6.73 \pm 0.53^{\mathrm{a}}$ & $6.64 \pm 0.61^{\mathrm{a}}$ \\
Osillatoria & $7.56 \pm 0.55^{\mathrm{a}}$ & $6.78 \pm 0.67^{\mathrm{b}}$ & $6.39 \pm 0.47^{\mathrm{b}}$ \\
Spirulina & $7.51 \pm 1.02^{\mathrm{a}}$ & $5.19 \pm 0.50^{\mathrm{b}}$ & $5.10 \pm 1.02^{\mathrm{b}}$ \\
\hline
\end{tabular}

There is significant difference between the numbers that are shown with the different letter(s) in each row $(\mathrm{p}<0.05)$.

The results obtained from the phytoplankton population assays showed that during the course of study, the percentage of Bacillariophyceae, Chlorophyceae and Cyanophyceae induced in LFAtreated ponds amounted to $10.2,48.9$ and $40.9 \%$ of total biomass, respectively, whereas percentages in treatment with LFB were 2.92, 94.42 and 2.65\%, respectively, and the GF treatment resulted in $8.04,16.82$ and $75.14 \%$, respectively.

This could be because the high concentration of nutrients and the immediate availability of inorganic nitrates and phosphates in the tank encouraged the growth of chlorophyte species in concordance with previous studies by Ansa and Akinwale (2007). Moreover, chlorophyte species belong to the "r" group of algae (As such they are often classed as opportunistic r-strategists (i.e. those organisms whose ecology is defined by a high growth rate, $r$ ), and they bloom in response to pulses of high-quality LFB, in contrast to the "k" group of algae (Furnas 1990), such as the cyanophyte species, that bloom and burst in response to low-quality fertilizer. Therefore, under 
identical climatic conditions and an equal biogenic consumption rate, LFB could produce higher amounts of chlorophyte biomass. As chlorophytes are among the most important algae consumed by phytoplankton-feeding fish, (Ludwig et al. 1998, Seymour 1980), using LFB to induce algal population density may be more profitable than using GF or LFA.

Table 3. Phytoplankton abundance of taxa recorded in treatments $(\log ($ cells/l).

\begin{tabular}{lccc}
\hline Family & \multicolumn{3}{c}{ Treatments (Mean \pm SD) } \\
\cline { 2 - 4 } & GF & LFA & LFB \\
\hline Bacillariophyta & $5.84 \pm 0.76^{\mathrm{a}}$ & $6.30 \pm 0.48^{\mathrm{a}}$ & $6.36 \pm 0.55^{\mathrm{a}}$ \\
Cholorophyta & $6.24 \pm 0.79^{\mathrm{b}}$ & $6.80 \pm 0.79^{\mathrm{b}}$ & $7.95 \pm 0.44^{\mathrm{a}}$ \\
Cyanophyta & $7.99 \pm 0.80^{\mathrm{a}}$ & $6.78 \pm 0.67^{\mathrm{b}}$ & $6.46 \pm 0.41^{\mathrm{b}}$ \\
Total algae & $8.12 \pm 0.79^{\mathrm{b}}$ & $7.42 \pm 0.20^{\mathrm{c}}$ & $9.28 \pm 0.43^{\mathrm{a}}$ \\
\hline
\end{tabular}

There is significant difference between the numbers that are shown with the different letter(s) in each row $(\mathrm{p}<0.05)$.

Cyanophytes are less digestible by shrimp and fish than cholorophytes and bacillariophytes (Stockner and Cronberg 2000, Villalon 1991), which has been clearly shown in the case of silver carp (Radke and Kahl 2002, Smith 1989). Because the total algal population density in the LFB treated tank was greater than that observed in ponds treated with granular fertilizer, chlorophytes must account for the majority of algal biomass in LFB treatment. However, in spite of the greater phytoplankton biomass observed in GF treatment, cyanophytes constituted the bulk of the algal population in the GF-treated pond, and these algae are of lower digestibility and have a lower absorption rate (Starling and Rocha 1990; Miura 1990). The results showed that the LFB strongly induced the chlorophyte population within the algal biomass (92.49\%). The chlorophyte population in treatment with LFA was 48.88 percent of the total algal biomass, and the population was $16.82 \%$ in the GF treatment. The combined percentages of bacillariophytes and chlorophytes amounted to $97.34 \%$ in LFB treatment, whereas the LFA and GF groups had 59.10 and $24.86 \%$, respectively. Thus, the comparisons show a significant difference $(\mathrm{p}<0.05)$ between the total algal biomass in LFA and GF treatment, and the overall algal population density of bacillariophytes and chlorophytes varied significantly in these two treatments.

Overall the results show that the gross and net photosynthetic products in the LFB treatment were higher than those observed in the two other treatments $(\mathrm{p}<0.05)$. In addition, the bacillariophytes showed no significant change among treatments $(p<0.05)$. However, the chlorophytes (in LFB) and cyanophytes (in GF) were increased relative to the other treatments $(\mathrm{p}<0.05)$.

Based on these findings, it is recommended that nursery ponds for raising finfish and crustacean larvae or those for the extensive culture of algal feed as live food organisms be fertilized with both granular fertilizer and liquid fertilizer, depending on the requirement for cyanophyte or chlorophyte species, respectively. The main species that should be used to feed fish and shrimp are Scenedesmus (fertilize with LFB) and Spirulina (fertilize with GF).

\section{References}

Aktan Y, Tufekci V, Tufekci H and Aykulu G 2005. Distribution patterns, biomass estimates and diversity of phytoplankton in Izmit Bay (Turkey). Est. Coast. Shelf Sci. 64: 72-384.

Ansa EJ and Akinwale MMA 2007. The potential suitability of nocturnally occurring plankton flora in earthen freshwater nursery ponds. Res. J. Appl. Sci. 2(6): 697-703.

AOAC 1995. Official Methods of Analysis, 16th ed. Association of Analytical Chemists: Arlington, VA. 
Arredondo JL and Ponce-Palafox JT 1998. La calidad del agua en acuicultura: Conceptos y Aplicaciones. AGT: Editors S.A. pp. 250

Boyd CE 1979. Water quality in warmwater fish ponds. Alabama Agricultural Experiment Station, Auburn University. Auburn, Alabama. pp. 235

Boyd CE 1981. Solubility of granular inorganic fertilizers for fish ponds. T. Am. Fish. Soc. 110: 451-454.

Boyd CE, Musig Y and Tucker L 1981. Effects of three phosphorus fertilizers on phosphorus concentrations and phytoplankton production. Aquaculture 22: 175-180.

Davidson RG and Boyd CE 1981. Phytoplankton response to liquid fertilizers. Prog. Fish. Cult. 43: 126-129.

Dodds W and Whiles M 2010. Freshwater Ecology: Concepts and environmental applications of Limnology. Academic Press. Burlington, MA 01803 USA.

Furnas MJ 1990. In situ growth rates of marine phytoplankton: Approaches to measurement, community and species growth rates. J. Plankton Res. 12(6): 1117-1151.

Geiger JG 1983. A review of pond zooplankton production and fertilization for the culture of larval and fingerling striped bass. Aquaculture 35: 353-369.

Ghosh M and Chattopadhyay NR 2005. Effects of carbon/nitrogen/phosphorus ratio on mineralizing bacterial population in aquaculture systems. J. Appl. Aquac. 17(2): 85-98.

Jana BB and Roy SK 1986. Seasonal and spatial distribution pattern of nitrogen fixing bacteria in fish ponds under different management systems. Hydrobiologia 137: 45-54.

Ludwig GM,. Stone NM and Collins C 1998. Fertilization of fish fry ponds. Southern Regional Aquaculture Center publication \#469. pp. 25.

Martin TD, Creed JT and Brockhoff CA 1994. Method 200.2 "Sample preparation procedure for spectrochemical determination of total recoverable elements.” Environmental Monitoring Systems Laboratory, Office of Research and Development. US Environmental Protection Agency, Cincinnati, Ohio. Revision 2.8 (1994).

Mischke CC and Zimba PV 2004. Plankton community responses in earthen channel catfish nursery ponds under various fertilization regimes. Aquaculture 233(1-4): 219-235.

Miura T 1990. The effects of planktivorous fishes on the plankton community in a eutrophic lake. Hydrobiologia 200/201: 567-579.

Nicholson WC 1983. Application of liquid fertilizer to hatchery ponds. Prog. Fish. Cult. 45: 223-225.

Ponce-Palafox JT, Arredondo-Figueroa JL, Castillo-Vargasmachuca SG, Rodríguez-Chávez G, Benítez-Valle A, Regalado de Dios MA, Medina-Carrillo F, Navarro-Villalobos R. Gómez-Gurrola JA and LópezLugo P 2010. The effect of chemical and organic fertilization on phytoplankton and fish production in carp (Cyprinidae) polyculture system. Revista Bio ciencias 1(1): 44-50.

Radke R and Kahl U 2002. Effects of a filter-feeding fish [silver carp, Hypophthalmichthys molitrix (Val.)] on phyto and zooplankton in a mesotrophic reservoir: results from an enclosure experiment. Freshw. Biol. 47: 2337-2344.

Sherrod LA, Dunn G, Peterson GA and Kolberg RL 2002. Inorganic carbon analysis by modified PressureCalcimeter Method. Soil Sci. Soc. Am. J. 66: 299-305.

Seymour EA 1980. The effects and control of algal blooms in fish ponds. Aquaculture 19: 55-74.

Smith DW 1989. The feeding selectivity of silver carp, Hypophthalmichthys molitrix Val. J. Fish Biol. 34: 819-828.

Starling FLRM and Rocha AJA1990. Experimental study of the impacts of planktivorous fishes on plankton community and eutrophication of a tropical Brazilian Reservoir. Hydrobiologia 200/201: 581-591.

Stirling HP 1985. Chemical and biological methods of water analysis for aquaculturists. Stirling: Institute of Aquaculture, University of Stirling. UK. p. 117.

Stockner JG and Cronberg G 2000. Picoplankton and other non-bloom forming Cyanobacteria in lakes. In: Whintton, B. A. and M. Potts (Eds.). The Ecology of Cyanobacteria. Kluwer Academic Publishers, the Netherlands, pp. 195-231. 
Utermöhl H 1958. Zur vervollkommnung der quantitativen Phytoplankton-Methodik. Mitt. Internat. Verei. Limnolo 9: 1-38.

Villalon JR 1991. Practical Manual for the Semi-intensive Commercial Production of Marine Shrimp. Texas A and M University Sea Grant College Program Publication. p. 104

Whatanabe FS and Olsen SR 1965. Test of ascorbic acid method for determining phosphorus in water and sodium bicarbonate extracts of soil. Soil. Sci. Soc. Am. Pro. 29: 677-678.

(Manuscript received on 25 July 2013; revised on 10 October, 2013) 